resonates with those of the other contributors. Something close to a consensus emerges among the contributors that equity seekers must mobilize among themselves, seek support from union leaders but retain their autonomy, and build strength and solidarity through multiple coalitions with other social justice and equity-seeking groups.

This collection, with its compelling argument that unions can no longer afford to treat equity as an unaffordable luxury, but as critical to their survival, its detailed analyses of the equity strategies that have failed, and its clear and detailed accounts of those that have succeeded, makes a valuable contribution to the literature on union renewal. Those engaged in the struggle to advance equity in their unions would do well to read the book and consider its arguments; they should encourage their union leaders to read it too.

Julie Guard

University of Manitoba

\title{
Samuel Moyn, The Last Utopia: Human Rights in History (Cambridge, MA, The Belknap Press of Harvard University Press, 2010).
}

Each year my course on "Human Rights in Historical Perspective" begins with an analysis of Adam Hochschild's Bury the Chains (Houghton Mifflin, 2005), and in particular its claim that the British abolitionist campaign was "History's first human rights movement". The students usually decide that it was not, some arguing that it was not the first, others that it was not a human rights campaign at all. Columbia University historian Samuel Moyn would agree with the latter group. In his thought-provoking book Moyn maintains that human rights as a genuine global phenomenon only began in the 1970s, with 1977 the "breakthrough year".

Moyn launches his argument with a disparagement of the historiography that has engaged in a "quixotic search for deep roots" of contemporary human rights. Only very recently have historians (or philosophers, for that matter) sought to trace a consistent trajectory for human rights to the ancient Greeks or Jews, to medieval Christians or Enlightenment scholars or eighteenth century revolutionaries. In the course of his attack, Moyn confronts the prevailing conventions in mainstream historical writing about human rights. Most controversially, perhaps, he dismisses the impact of World War II and the Holocaust, popularly assumed (with considerable academic support) to have generated a reaction that led to the adoption of the Universal Declaration of Human Rights in 1948. Furthermore, he claims, non-governmental organizations had no real hand in introducing human rights to the international agenda in 1945-1948, the Declaration was not cross-cultural in formulation or principles, and it remained 
marginal for decades because it did not truly represent the popular will at that time. Human rights were "dead at birth".

In the place of these alleged myths, Moyn posits a radical thesis. In the 1970s other utopian visions - Communism, nationalism, anti-colonialism, popular revolution - either self-destructed or were discredited, leaving human rights as the only available ideology. Human rights did not triumph, in this sense; they simply survived when other visions failed. Their positive attraction was that they were apolitical, distinct from the damaging rivalries of the Cold War. They are "the last utopia" of his title. But then, having achieved hegemony, human rights were transformed: they moved "from morality to politics, ... from charisma to bureaucracy". Thus, he concludes, they evolve into that which they replaced.

Moyn has amassed considerable evidence to demonstrate a blossoming of human rights interest in the late 1970s: dissidents in Eastern Europe and the Helsinki Accords, anti-dictatorship movements in Latin America, disillusionment at the failure of colonial independence to deliver democracy, a membership explosion and a Nobel Prize for Amnesty International, above all US President Jimmy Carter's "absolute" commitment to human rights. But this falls short of deserving the term "breakthrough" or the launching of a "true" version of universal rights. For one thing, Moyn offers no definition of "human rights" that would draw a clear distinction between his and earlier versions. For another, the Soviet Empire, Latin American dictatorships, African kleptocracies and South African Apartheid remained in oppressive operation for another decade or more, not to mention America's swift retreat from the Carter commitment. Where do Abu Ghraib and Guatanamo feature in the new utopia, or the Balkans or Rwanda? And, as events in North Africa have demonstrated in early 2011, the last utopia is misnamed. The crowds in the streets and the squares are recalling earlier utopias, of mass demonstrations and cries for domestic democracy; there is even armed revolution.

Human rights have meant different things at different times. Moyn is correct to argue that their history has been discontinuous and contingent, but he fails to recognize that his 1970s are another historical example, a cluster of events to be analysed for their meaning along with all other outbursts of "rights discourse" and their achievements, or disappointments. Instead of dismissing earlier ramifications as non-precursors he could examine their common characteristics, such as the demand by people to change a power relationship that oppresses them or others for whom they care. "Agency", missing from Moyn's account, is the one connecting link. Social movements, not American presidents, are the source of rights innovations, a lesson taught by abolitionism just as poignantly as the "breakthrough" 1970s.

The Last Utopia is an intriguing read, industriously researched, challenging almost every assumption about human rights. It is an important and essential book, and it will appear on my course reading list along with Hochschild's. Moyn 
does not convince, but he will prompt new thinking. As such the publication of The Last Utopia may come to be considered a significant "breakthrough" in the historiography of human rights.

James W. St.G. Walker

University of Waterloo

\section{Martin Klimke, The Other Alliance: Student Protest in West Germany and the United States in the Global Sixties (Princeton, NJ: Princeton University Press, 2010).}

One hundred and fifty years ago Charles Darwin inveighed against the view that a scientist's role is one of observing, rather than theorising. One "might as well go into a gravel-pit and count the pebbles and describe the colours," argued the great naturalist. "[A]ll observation must be for or against some view if it is to be of any service." I would add that in history observation itself is never neutral: if an historian first does not situate himself in his own history, what he takes to be simple observations in reality are reflections of the dominant power relations of the society in which he lives. Reading Martin Klimke's The Other Alliance: Student Protest in West Germany and the United States in the Global Sixties painfully brings Darwin's thoughts to mind.

Klimke sets three goals for his book. First, he proposes to explore "the exact processes through which [New Left] activists" from the United States and West Germany "established contact, shared ideas, and adopted each other's social and cultural practices" (2). Klimke terms this relation between U.S. and West German activists the "other alliance," in contrast to the "official transatlantic partnership" between the United States and West Germany [7]. Second, Klimke proposes to use the US-West German relation "as a case study," in order to show "for the very first time how the U.S. government monitored and reacted to the global student protest during the 1960s" [2]. Finally, Klimke hopes that his study will "contribute to an explanation of the internationality of the sixties and this decade's role in the postwar political order" [7].

Klimke partially succeeds in meeting his first two goals. He leaves no stone unturned in going through archives on both sides of the Atlantic and uncovering the numerous connections between the American Students for a Democratic Society (SDS) and the (West) German Socialist Student League, Sozialistischer Deutscher Studentbund (SDS). He is equally diligent in exploring both U.S. and West German governmental evaluations of Germany's SDS.

Unfortunately, to understand why the two SDSes were able to share and exchange ideas involves far more than tracing the connections between the organizations. If New Leftists from the U.S. and from West Germany drew on 